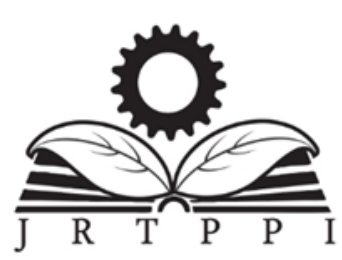

Vol. 11 No. 1 (2020) 12-18

Jurnal Riset

Teknologi Pencegahan Pencemaran Industri

Kementerian

Perindustrian

REPUBLIK INDONESIA

Journal homepage : http://www.jrtppi.id

\title{
Performance of a Full-Scale Anaerobic Digestion on Bakery Wastewater Treatment : Effect of Modified Distribution System
}

Hanny Vistanty ${ }^{1 *}$, Rizal Awaludin Malik', and Aris Mukimin

${ }^{1}$ Center of Industrial Pollution Prevention Technology, Jl. Kimangunsarkoro no. 6, Semarang, Indonesia

\begin{tabular}{l} 
A R T IC L E I N F O \\
\hline Article history: \\
Received 23 March 2020 \\
Received in revised form 15 April 2020 \\
Accepted 20 April 2020 \\
Available online 21 May 2020
\end{tabular}

Keywords :

Internal Circulated

Anaerobic Digestion

Bakery Wastewater

\begin{abstract}
A B S T R A C T
The effectiveness of a full-scale anaerobic digestion pretreatment was evaluated and the effect of wastewater distribution system was determined on the performance of bakery wastewater (BW) treatment. The BW was fed to 3 series of anaerobic compartments as the main degradation process. The distribution system of first compartment was modified and circulated to enhance contact and efficiency. While the effluent of last compartment was partly returned to the first compartment as an external circulation and the other part was further processed in activated sludge under aerobic conditions. The overall system was able to remove chemical oxygen demand (COD), total suspended solids (TSS), and biochemical oxygen demand (BOD) up to $97.7 \%$, $99.7 \%$, and $99.6 \%$, respectively, at maximum organic loading rate of $6.3 \mathrm{~kg} \mathrm{COD} / \mathrm{m}^{3}$ day and internal and external circulation rate of $10 \mathrm{~L} / \mathrm{min}$ and $15 \mathrm{~L} / \mathrm{min}$, respectively. High removal of pollutants indicated that modified distribution of circulation is advantageous to the BW treatment.
\end{abstract}

\section{INTRODUCTION}

Food industry shows a promising trend in order to meet the rising demand of food products, including biscuit, bakery, and dairy products. The market of food products in Indonesia has grown in a range of $5-10 \%$ annually and contributes up to 700 trillion rupiah of gross domestic income. Aside from the positive effect, it also may inflict negative consequences towards the environment, especially due to wastewater generated. Food industries, especially biscuit and bakery, consume large volume of water in their washing process that is discharged as wastewater. Bakery wastewater (BW) generated mainly contains flour, sugar, and high concentration of fat, oil, and grease (FOG) (de Santana, Zanoelo, Benincá, \& Freire, 2018). It is generally high strength and contains high concentration of suspended and soluble organics with high chemical oxygen demand (COD) and biochemical oxygen demand (BOD) and low biodegradability ratio. Thus a proper wastewater manage ment is urgently needed to avoid high environmental risk.

Implementation of electrocoagulation method as bakery wastewater treatment was studied and the results showed that it efficiently separated insoluble FOG (de Santana et al., 2018). The author mentioned that it showed high performance in removing turbidity, color and grease. However, it was ineffective in removing soluble organic contained, therefore, the effluent still showed a high concentration of COD and BOD and it was applied only as a pretreatment prior to anaerobic digestion. Some conventional processes were also used, namely aerobic process, however the presence of oil layer in wastewater may wrap microorganisms and reduced the performance and efficiency (Pereira, Sousa, Mota, \& Alves, 2004).

Previous studies applied anaerobic digestion FOGcontaining wastewater treatment (Cammarota \& Freire, 2006; Masse, Massé, \& Kennedy, 2003; Wan, Zhou, Fu, \& Li,

*Correspondence author. Tel. : +6287832782426

E-mail : hannyvistantybbtppi@gmail.com (H. Vistanty) 
2011). The author combined anaerobic digestion with hydrolysis pretreatment using Pancreatic Lipase as a way to enhance fat digestion (Masse et al., 2003). However, it only had a small effect on fat digestion (5\%) compared to control substrates. In addition to that, pretreatment needs additional space and cost.

Lipids, as the main component of BW, are generally categorized into five types of form, namely, floating, dispersed, emulsion, soluble, and solid substances (Ren, Nie, Liu, \& Jin, 2006). Floating, dispersed, and solid forms, are highly possible to be removed physically, while the emulsion and soluble forms are mostly difficult to separate. Soluble lipids are prone to form layer on the surface of microorganisms and particles, thus preventing further contact between pollutant and microorganism. In some cases, lipid-coated microorganisms are floated to the surface and washed out of the anaerobic reactor, thus will reduce the system performance.

In addition to fat particles, anaerobic digestion of FOG-containing wastewater is also constrained by the high possibility of $\mathrm{pH}$ drop as a result of accumulation of volatile fatty acids (VFA) produced by lipid hydrolysis. VFA overload may cause disturbance to anaerobic system as it will create an imbalance of acid and methane production. Process modification, such as, leachate recirculation to hydrolysis process was applied to prevent system failure on anaerobic system due to VFA overload (Veeken \& Hamelers, 1999). Another report mentioned increased contact intensity between biomass and wastewater resulting into a higher performance of degradation (Wang, Xu, Yan, \& Yu, 2014). Internal circulation has been intensevely applied on various wastewater treatment, such as tofu, brewery, and citric acid (Cui, Zhou, \& Zhang, 2011; Deng, Zheng, \& Chen, 2006; Vistanty \& Malik, 2019). Anaerobic system with recirculation was improved in respect of system and $\mathrm{pH}$ stability and showed improved COD removal. Considering the challenge of wastewater treated and the advantages of wastewater flow modification, this study aims to modify the distribution system of wastewater fed to anaerobic unit to improve the performance and minimize the effect of fat insoluble particles, and to evaluate the effect in a full-scale FOG wastewater treatment process.

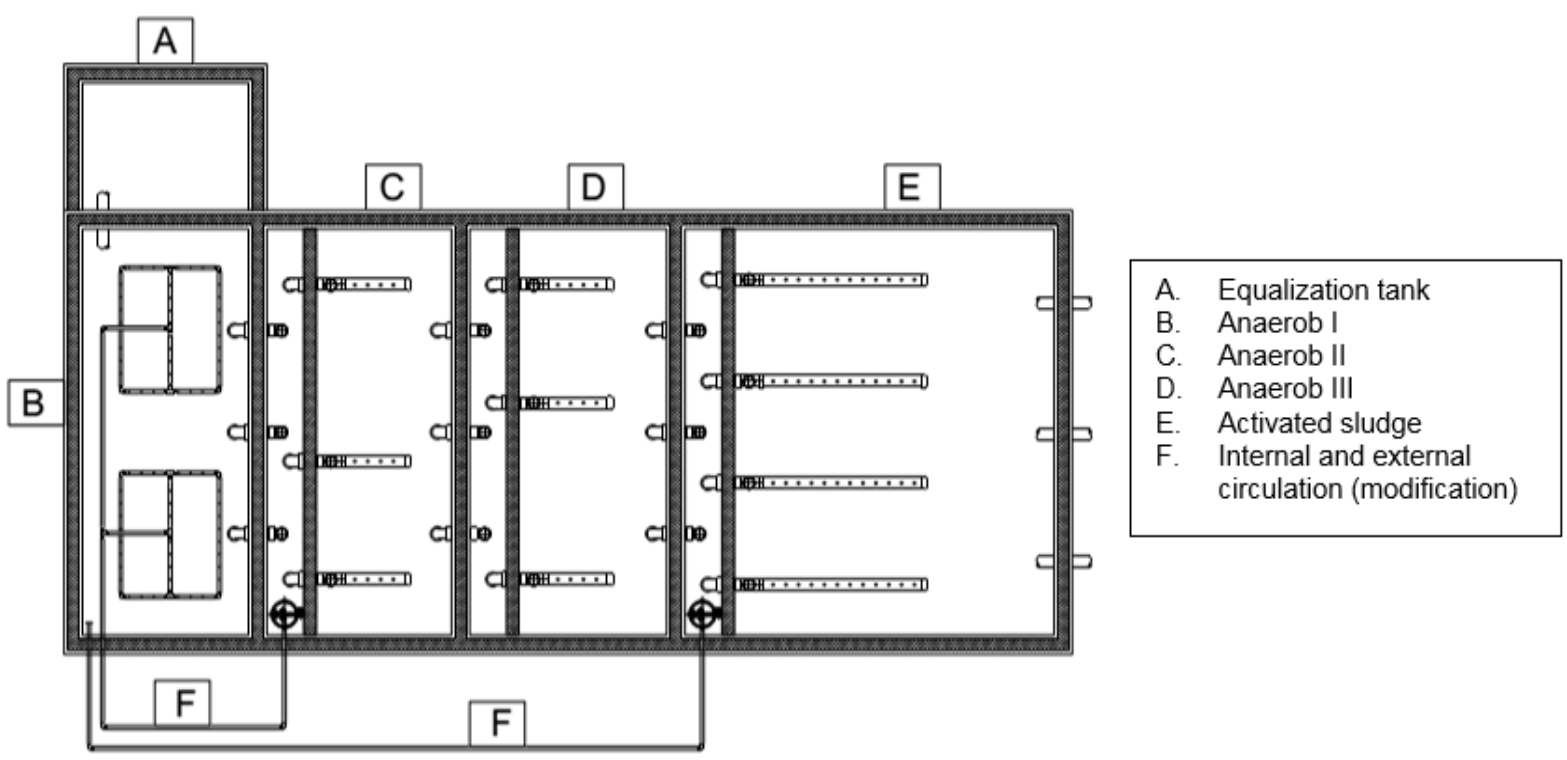

Fig. 1. Layout of wastewater flow modification and recirculation 
Table 1. Wastewater characteristics as influent

\begin{tabular}{lll}
\hline \multicolumn{1}{c}{ Characteristic } & \multicolumn{2}{c}{ Measurement } \\
\hline Total suspended solids $(\mathrm{mg} / \mathrm{L})$ & 1124 & 881 \\
Biochemical Oxygen Demand $(\mathrm{mg} / \mathrm{L})$ & 1603 & 3389 \\
Chemical Oxygen Demand $(\mathrm{mg} / \mathrm{L})$ & 3984 & 9672 \\
$\mathrm{pH}$ & 3.5 & 3.8 \\
\hline
\end{tabular}

Samples were analyzed in BBTPPI laboratory
Table 2. Summary of wastewater treatment plant

\begin{tabular}{lccc}
\hline \multicolumn{1}{c}{ Unit } & HRT (h) & pH & COD \\
\hline Anaerobic I & 38.8 & 4.1 & 5824 \\
Anaerobic II & 39.2 & 5.5 & 3957 \\
Anaerobic III & 41.8 & 5.6 & 3531 \\
Activated sludge & 52.2 & 6 & 2800 \\
\hline
\end{tabular}

HRT obtained from the industry, $\mathrm{pH}$ was measured in situ and COD was measured in BBTPPI laboratory
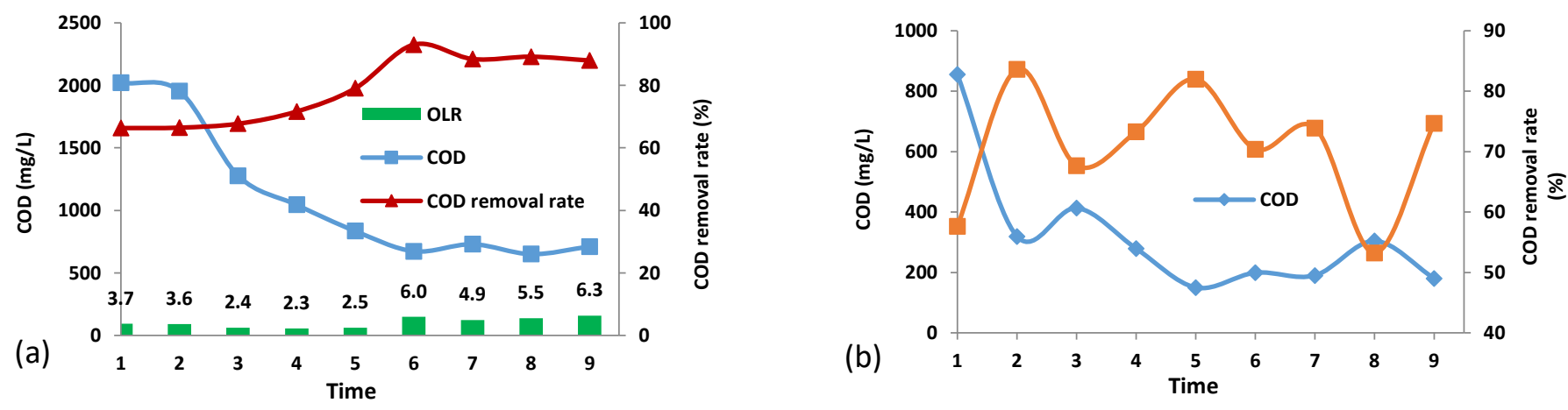

(c)

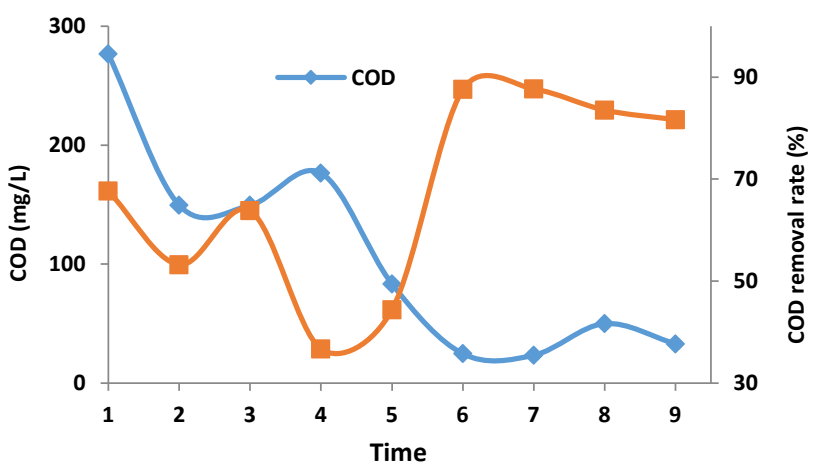

Fig. 2. COD profile and removal rate of (a) anaerobic I, (b) anaerobic II, and (c) anaerobic II

\section{METHODS}

\subsection{Experimental setup}

The schematic diagram of modified distribution and recirculation applied in an existing full-scale wastewater treatment (WWT) plant of a bakery industry is shown in Fig. 1. The WWT plant has three-staged anaerobic system and an activated sludge unit connected in series. Anaerobic unit was targeted because it is considered as the main engine in the degradation process in the WWT plant. Wastewater flow was modified by establishing a new internal circulation in the first compartment of anaerobic reactor and external circulation by feeding the outlet of third compartment into the first compartment of anaerobic reactor. Internal and external circulation was distributed in a separated pipeline and different setting of distribution. Internal circulation was taken from the outlet of the first stage and pumped back as feed, while external circulation was taken from the outlet of the third stage and partly fed to the first stage. Recirculation system used pipes of 0.5 inch diameter and wastewater was distributed via $3 \mathrm{~mm}$ diameter holes on the side of pipes.

COD removal rate was investigated under constant internal of $10 \mathrm{~L} / \mathrm{min}$ and external circulation rate of $15 \mathrm{~L} / \mathrm{min}$. HRT was maintained constant (Table 2) at inlet flowrate of $890 \mathrm{~L} / \mathrm{h}$, while OLR was fluctuated dependent on the inlet COD concentration. Raw wastewater was fed to WWT plant for $8 \mathrm{~h}$, while internal and external circulations were applied for $24 \mathrm{~h}$. 


\subsection{Wastewater characteristics}

Wastewater treatment plant received wastewater from production line, generated from utility washing process. The influent is characterized as fat-rich high organic, high suspended solids, and turbid wastewater. Wastewater characteristics and plant operation variables were directly obtained from the industry (Table 1 and 2). Samples were taken from the equalization tank and analyzed in our laboratory.

\subsection{Analysis methods}

Effect of modification was monitored regularly by collecting samples from each anaerobic compartment every 2 days. Monitoring was carried out by measuring Chemical Oxygen Demands (COD), volatile fatty acids (VFA), and alkalinity. COD removal rate was measured to evaluate the performance of each unit, while VFA and alkalinity was measured to observe the stability of anaerobic system. BOD, COD and alkalinity were measured in accordance to Standard Methods (5210 B, 5220 C and 2320 B) (E.W. Rice, R.B. Baird, A.D. Eaton, 2017). VFA was determined using modified spectrophotometric method (Siedlecka \& Kumirska, 2008) while handheld $\mathrm{pH}$ meter was used to record $\mathrm{pH}$ fluctuation during modification and experiment.

\section{RESULT AND DISCUSSION}

\subsection{COD removal rate}

$\mathrm{COD}$ is evaluated as a main parameter in assessing the WWT performance, because the characteristics of wastewater

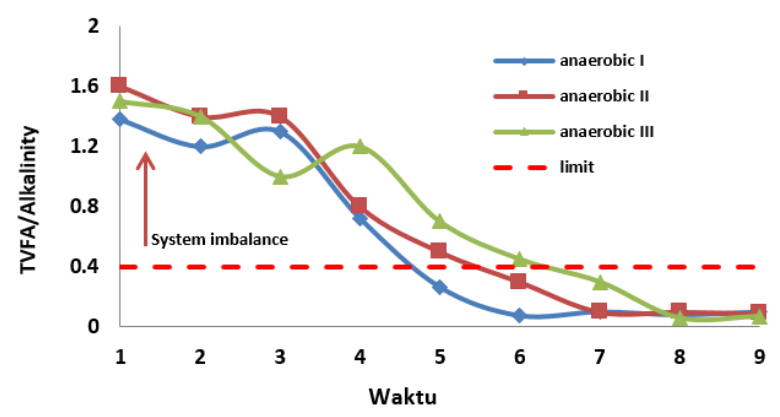

Fig. 3. TVFA/alkalinity ratio of anaerobic unit after modification treated is dominated by varied compounds, such as, fat or grease and sugar. Thus, COD removal rate was monitored and plotted to assess the stability of anaerobic unit (Fig. 2).

Due to the application of internal and external circulation at $5 \mathrm{~L} / \mathrm{min}$ and $7 \mathrm{~L} / \mathrm{min}$, respectively, the upflow velocity was increased twofold from $0.235 \mathrm{~m} / \mathrm{h}$ into 0.588 $\mathrm{m} / \mathrm{h}$. It leads into an enhanced mass transfer and contact between wastewater and biomass, which then directly improves degradation process.

As can be seen in Fig. 2, anaerobic I shows a more stable system compared to anaerobic II and III. A significant drop of COD was observed on the third day and gradually decreased to $673 \mathrm{mg} / \mathrm{L}$. COD removal rate was also increased and reached $93 \%$, even when the OLR was significantly increased to $6 \mathrm{~kg} \mathrm{COD} / \mathrm{m}^{3} \mathrm{~d}$. It is in accordance to the TVFA/alkalinity ratio (Fig. 3), which indicates anaerobic stability. It is more stable than result reported in other studies which mentioned an early stage of overloading due to TVFA in two-stage anaerobic system (Zuo, Wu, Qi, \& Dong, 2015). In contrast with anaerobic I, anaerobic II and III show a relatively fluctuated trend in regards of COD removal rate. It is possibly due to the absence of circulation system in anaerobic II and III, which resulted in slower response of anaerobic system to the organic load. However it shows an increase of COD removal rate in the latter stage of observation. It can be concluded that the anaerobic I is the first shield and do the main portion in degradation process, while anaerobic II and III are indirectly affected.

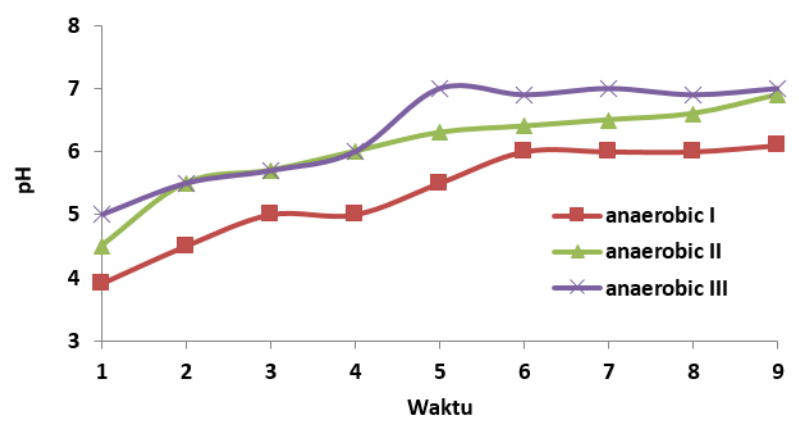

Fig. 4. $\mathrm{pH}$ trend of anaerobic unit after modification 
Table 3. Effluent of wastewater treatment plant after modification

\begin{tabular}{lcccc}
\hline Parameters & $\mathbf{1}$ & $\mathbf{2}$ & $\mathbf{3}$ & Standard \\
\hline TSS & 25 & 63 & 42 & 85 \\
BOD & 25.15 & 11.29 & 32.7 & 85 \\
COD & 38.28 & 62.15 & 45.56 & 175 \\
pH & 8.6 & 8.6 & 8.0 & $6-9$ \\
\hline
\end{tabular}

\subsection{Total VFA/alkalinity ratio and $\mathrm{pH}$ trend}

Previous study mentioned that anaerobic digestion without recirculation was more susceptible to VFA overload and may lead to shock and inflict disturbance to anaerobic digestion (Zuo et al., 2015). VFA overload generally happens because the acidification stage of anaerobic system occurs faster than methanation. Thus, recirculation will transfer excessed VFA to be processed in the first stage of anaerobic digestion. Active methanogenic effluent will also be circulated and transferred to acidification stage and facilitate the methanation process. Alkalinity also holds a great role in maintaining the system stability and acts as $\mathrm{pH}$ buffer. In low $\mathrm{pH}$ environment, alkalinity will be used to maintain system $\mathrm{pH}$ and provide the optimal condition for methanation.

To monitor and identify any disturbance to the anaerobic system, we monitored total volatile fatty acid (TVFA) and alkalinity ratio (TVFA/alkalinity) as a key indicator. As shown in Fig. 3., in the early stage of experiment TVFA/alkalinity ratio of the anaerobic digestion was approximately 1.38 , much higher than $0.3-0.4$, which is known as the maximum limit to process stability. When TVFA/alkalinity ratio is more than 0.4 , then the anaerobic digestion can be concluded as instable and is in risk of excessive acidification (Sánchez, Borja, Travieso, Martín, \& Colmenarejo, 2005). As recirculation applied, TVFA/alkalinity ratio was significantly decreased less than 0.4 , indicating that system has recovered its stability.

Other than VFA, effluent recirculation will increase $\mathrm{pH}$ in the early stages of anaerobic system, which will establish an optimal condition for methanation step (Fig. 4). It is evident in the result of our experiment, in which before modification, $\mathrm{pH}$ value in each unit was relatively low (around 4-5), while after recirculation, $\mathrm{pH}$ in anaerobic I was significantly increased to 6 and subsequently improved $\mathrm{pH}$ value in anaerobic II and III. It was possible because continuous circulation system will return a part of anaerobic III to anaerobic I which then directly increase $\mathrm{pH}$ on the system. It can be concluded that both $\mathrm{pH}$ and VFA reduction is linking and any change in one variable will affect the other.

\subsection{Effects of recirculation modification on the performance of WWT plant}

In addition to specific parameters, such as, COD, VFA, alkalinity, and $\mathrm{pH}$ of anaerobic system, this study also evaluates the performance of whole system of wastewater treatment plant. It aims to ensure that the final effluent can meet the discharge standard of local regulation. As shown in Table 3, the effluent of last stage of WWT plant, i.e., activated sludge was able to meet the water quality standard for discharge to receiving water body in Central Java. The overall wastewater treatment plant was able to remove TSS, BOD, and COD up to $97.7 \%, 99.7 \%$, and $99.6 \%$, respectively. A similar COD removal rate was also reported $(96.2-97.5 \%)$ by another study treating soybean wastewater with square internal circulation anaerobic tank (Zeng, Hou, \& Cui, 2011).

\section{CONCLUSION}

Modification in distribution system was applied in wastewater treatment plant (WWTP) of a biscuit industry in Central Java. Application of internal and external circulation exhibited great influence in improving system stability, indicated by decreasing trend of TVFA/alkalinity ratio to less than 0.4 . COD removal rate was up to $93 \%, 82 \%$, and $87 \%$ on anaerobic I, II, and III, respectively. $\mathrm{pH}$ value at anaerobic unit was also improved by recirculation system, and increased to more than 6. Based on these results, it is concluded that recirculation system positively affected wastewater treatment 
and can be a solution to overcome instability and shock to anaerobic digestion.

\section{REFERENCES}

Cammarota, M. C., \& Freire, D. M. G. (2006). A review on hydrolytic enzymes in the treatment of wastewater with high oil and grease content. Bioresource Technology, 97(17), 2195-2210. https://doi.org/ 10.1016/j.biortech.2006.02.030

Cui, P., Zhou, X., \& Zhang, Y. (2011). The Feasibility Study of Cotton Pulp Wastewater Treatment with IC Anaerobic Reactor. Procedia Environmental Sciences, 11, 686-692. https://doi.org/10.1016/ J.PROENV.2011.12.107

de Santana, M. M., Zanoelo, E. F., Benincá, C., \& Freire, F. B. (2018). Electrochemical treatment of wastewater from a bakery industry: Experimental and modeling study. Process Safety and Environmental Protection, 116, 685-692. https://doi.org/10.1016/ j.psep.2018.04.001

Deng, L.-W., Zheng, P., \& Chen, Z.-A. (2006). Anaerobic digestion and post-treatment of swine wastewater using IC-SBR process with bypass of raw wastewater. Process Biochemistry, 41(4), 965-969. https://doi.org/10.1016/J.PROCBIO.2005.10.022 and performance of a secondary upflow anaerobic sludge bed reactor treating piggery waste. Bioresource Technology, 96(3), 335-344. https://doi.org/10.1016/j.biortech.2004.04.003

Siedlecka, E., \& Kumirska, J. (2008). Determination of volatile fatty acids in environmental aqueous samples. Polish Journal of Environmental Studies, 17(3), 351356. Retrieved from http:// www.6csnfn.pjoes.com/pdf/17.3/351-356.pdf

Veeken, A., \& Hamelers, B. (1999). Effect of temperature on hydrolysis rates of selected biowaste components. Bioresource Technology. https://doi.org/10.1016/S0960-8524(98)00188-6

Vistanty, H., \& Malik, R. A. (2019). Enhanced Performance of Multi-Stage Anaerobic Digestion of Tofu Wastewater: Role of Recirculation. Jurnal Riset Teknologi Pencegahan Pencemaran Industri, 10(1),
E.W. Rice, R.B. Baird, A.D. Eaton, editors. (2017). Standard Methods for the Examination of Water and Wastewater. 23rd ed. American Public Health Association, Washingto, DC, USA. https://doi.org/ ISBN 9780875532356

Masse, L., Massé, D. I., \& Kennedy, K. J. (2003). Effect of hydrolysis pretreatment on fat degradation during anaerobic digestion of slaughterhouse wastewater. Process Biochemistry, 38(9), 1365-1372. https://doi.org/10.1016/S0032-9592(03)00020-7

Pereira, M. A., Sousa, D. Z., Mota, M., \& Alves, M. M. (2004). Mineralization of LCFA associated with anaerobic sludge: Kinetics, enhancement of methanogenic activity, and effect of VFA. Biotechnology and Bioengineering, 88(4), 502-511. https://doi.org/10.1002/bit.20278

Ren, L., Nie, Y., Liu, J., \& Jin, Y. (2006). [Impact of hydrothermal process on the dewaterability and degrease performance of restaurant garbage]. Huan Jing Ke Xue= Huanjing Kexue, 27(9), 1906-11. Retrieved from http://www.ncbi.nlm.nih.gov/ pubmed/17117654

Sánchez, E., Borja, R., Travieso, L., Martín, A., \& Colmenarejo, M. F. (2005). Effect of organic loading rate on the stability, operational parameters

29-37.

Wan, C., Zhou, Q., Fu, G., \& Li, Y. (2011). Semi-continuous anaerobic co-digestion of thickened waste activated sludge and fat, oil and grease. Waste Management, 31(8), 1752-1758. https://doi.org/10.1016/ j.wasman.2011.03.025

Wang, J., Xu, W., Yan, J., \& Yu, J. (2014). Study on the flow characteristics and the wastewater treatment performance in modified internal circulation reactor. Chemosphere, 117(1), 631-637. https://doi.org/10.1016/j.chemosphere.2014.09.088

Zeng, K., Hou, Y. J., \& Cui, Y. P. (2011). The research of square internal circulation anaerobic reactor to treatmenting soybean protein wastewater. In 2011 International Conference on Multimedia Technology, ICMT 2011 (pp. 1329-1332). https://doi.org/10.1109/ICMT.2011.6001735 
Zuo, Z., Wu, S., Qi, X., \& Dong, R. (2015). Performance enhancement of leaf vegetable waste in two-stage anaerobic systems under high organic loading rate:
Role of recirculation and hydraulic retention time. Applied Energy, 147(17), 279-286. https://doi.org/ 10.1016/j.apenergy.2015.03.001 